Nig. J. Biotech. Vol. 37(2): 152-156 (Dec. 2020)

ISSN: 01891731

Available online at

http://www.ajol.info/index.php/njb/index

and www.biotechsocietynigeria.org

DOI: https://dx.doi.org/10.4314/njb.v37i2.15

\title{
Intraspecific Hybridization Of Normal Pigmented And Albino Clarias Gariepinus From Yola And Katsina under Hatchery Condition
}

\author{
*Onyia, L.U, ${ }^{1}$ Ochokwu, I.J ${ }^{2}$. and V. Robinson ${ }^{3}$ \\ ${ }^{1}$ Department of Fisheries, ${ }^{3}$ Department of Zoology, Modibbo Adama University of Technology PMB \\ 2076, Yola. \\ 2Department of Fisheries and Aquaculture, Federal University Dutsinma, PMB 5001, \\ Katsina State - Nigeria
}

\section{Abstract}

The study examined the reproductive indices of albino and normal pigmented Clarias gariepinus fish from Katsina (KT) and Yola (YY), carried out under hatchery condition. The experiment compared the fecundity, testes, milt volume, percentage fertilization and hatchability of albino (AA) and normal pigmented (NN) Clarias gariepinus from Katsina (KT) and Yola (YY). Normal pigmented C. gariepinus from Katsina (KT) had the highest number of eggs $(229,240)$, followed by $Y Y(127,250)$ and the least was recorded in the Albino (AA) (124,750). The weights and lengths of the left and right lobes as well as the volumes of the milt were quantified . However, $\mathrm{KT}$ had the highest weight and length of the right testis $(18 \mathrm{~g}$ and $5.7 \mathrm{~cm}$ respectively) while AA had the highest weight, length of the left testis and milt volume $(30 \mathrm{~g}, 11 \mathrm{~cm}$ and $8.4 \mathrm{ml}$ respectively). The least length and weight of the testes was observed in YY. Meanwhile, KT and YY had milt volumes of $4.0 \mathrm{ml}$ and $4.7 \mathrm{ml}$, respectively. The highest percentage fertilization and hatchability were recorded in KT $\times$ KT $(98.7 \%$ and $98.5 \%$ respectively) among the purebred, while KT $\times$ AA had the highest percentage fertilization and hatchability (98.4\% and $97.3 \%$ respectively) in the reciprocal hybrids. The percentage fertilization and hatchability among the genetic crosses showed significant differences $(p<0.05)$. The results deduced the essentiality of fish hybridization. Furthermore, crossing of broodstocks from different regions have showcased the contingency of acquiring fish seed of improved reproductive potentials in the reciprocal hybrids in the aspects of fecundity, fertilization, hatchability rate, testis quality and faster growth.

Keywords: Albino, Fecundity, Intra-specific Hybridization, Normal pigmented, Testis.

*Correspondence Author: fineije@gmail.com; Phone number: +2348060907861

\section{Introduction}

Fish hybridization is the crossing of different fish species, genera as well as families from first filial generation, backcrossing or out crossed to give hybrids of desired qualities. However Adah et al. (2014) reported that hybridization is a process of generating a new form of animal through human intervention (Aquaculture) or naturally by crossing genes of different species. Onyia et al. (2017) defined intra-specific hybridization as a cross between different strains of the same species for the purpose of increasing growth rate, feed conversion ratio and survival. Fish hybridization is an essential genetic technique that removes undesirable characteristics such as inbreed, deformity while retaining the desirable traits (Ochokwu et al., 2016). Intraspecific hybridization involves the same species but from different hydrological zones (Onyia et al.,2011). Hybridization has been used to improve fish, increase growth rate, manipulate fish sex, produce sterile fish, and improve flesh quality, increase semen volume, increase disease resistance, and environmental tolerance (Ochokwu et al., 2016). It also produces offspring that perform 
better than both parental fish species (positive heterosis).

Albino African catfish are like other animal albinos that result from genetic anomaly that causes them to lack pigment, thereby appearing white (Onyia et al., 2016). There are albinos among the African catfishes in the wild, however, the light coloration makes them easier to be spotted by predators therefore reducing their population. The word albinism is from discontinuous genetic variation generated by inability of or absence of genes that determine the production of the dark pigment melanin in fish skin cells (Onyia et al., 2016,2018). In some cases, the absence of colours is related to mutations of the tyrosinase genes. However, Sazima and Pombal Jr, (1986) reported cases of albinism that are as a result of chromatic anomalies with total or partial pigmentation. The aim of the study is to determine the fertility, hatchability and survival of normal pigmented and albino C. gariepinus through Intra-specific hybridization.

\section{Materials and Methods}

The study area

The study was conducted in the Department of Fisheries, Teaching and Research Farm, Modibbo Adama University of Technology Yola, Adamawa State, Nigeria.

\section{Source of Broodstock}

Male (3000g) and female (750g) Albino (AA) brood fish were purchased from Tiva Fish Farm Nigeria Limited, Numan road Yola while the normal pigmented male and females (YY) weighing $750 \mathrm{~g}$ each were collected from the Department of Fisheries, Teaching and Research Fish Farm, Modibbo Adama University of Technology Yola and Shangai Farms Katsina State (KT). The Albino and Shangai broodstock were acclimatized for one week in a concrete tank of $2 \mathrm{~m} \times 1.5 \mathrm{~m}$. During the period of acclimatization, they were fed with a $35 \%$ crude protein diet twice daily at $3 \%$ body weight.

\section{Induced breeding}

The broodstocks were induced by injecting Ovaprim at $0.5 \mathrm{ml} / \mathrm{kg} / \mathrm{fish}$. After the latency period, the eggs from the females were stripped into dry receptacles. The males were sacrificed and testes collected to fertilize the eggs. The crosses were done in triplicates: KT male $\times \mathrm{KT}$ female $\left(\mathrm{O}^{\prime} \mathrm{KTCg} \times \subsetneq \mathrm{KTCg}\right), \mathrm{YY}$ male $\times Y Y$ female $\left(\left(\sigma^{r} Y Y \times Y Y\right.\right.$ $\left.\left.Y g\right)\right)$ Albino male $x$ Albino female ( $0^{x} \mathrm{AACg} \times \odot \mathrm{AACg}$ ), KT male $\times$ Albino female ( ${ }^{\circ} \mathrm{KT} \times \mathrm{AA}$ ( $\mathrm{Cg}$ ) Albino male $\times$

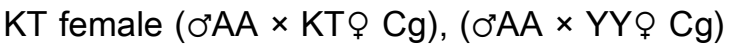
and $Y Y$ male $\times$ Albino female $\left(O^{\prime} Y Y \times A A @ C g\right)$ respectively.

\section{Reproductive parameters}

The total weight of the eggs/broodstocks were taken, $1 \mathrm{~g}$ of eggs was counted and multiplied by the total weight of the eggs to get the fecundity of the broodstocks. The weights and lengths of the left and right lobes of the testes from each male were taken and recorded. The milt volume of the testes from each male was recorded. Analytical balance with precision of $0.01 \mathrm{~g}$ (model: Scout Pro SPU123, Ohaus Corporation, USA) was used to measure the weights of the eggs and testes.

\section{Percentage Fertilization}

One hundred and fifty fertilized eggs from each treatment were counted into a petri-dish in triplicate. This was observed after thirty minutes and unfertilized eggs (white in colour) were counted and subtracted from the one hundred and fifty to give the number of fertilized eggs. Percentage fertilization was calculated using the formula below:

$\%$ Fertilization $=$ Total number of fertilized eggs/total number of incubated eggs $\times 100$ $\%$ Hatchability = Total number of hatched eggs/ Total number of incubated eggs $\times 100$

\section{Statistical analyses:}

Data collected from the experiments were subject to one-way-Analysis of Variance (ANOVA). Differences between the means were determined using DMRT $(p=0.05)$ using SPSS version 20.

\section{Results}

The weight of the female broodstock was $750 \mathrm{~g}$, the length was $44.5 \mathrm{~cm}$ except for the Albino that had $45.5 \mathrm{~cm}$ as shown in Table 1 . The fecundity rate was significantly higher $(p<0.05)$ in fish from Katsina $(229,240)$, followed by Yola $(127,250)$ and the least was in 
the Albino $(124,750)$. The same trend was observed in the weights of the eggs.

Table 1: Mean Fecundity of Albino and Normal Pigmented Clarias gariepinus Broodstock

\begin{tabular}{llllll}
\hline $\begin{array}{l}\text { Female } C \\
\text { gariepinus }\end{array}$ & Weight $(\mathrm{g})$ & Length $(\mathrm{cm})$ & Wt. of eggs & $\begin{array}{l}\text { No. in } 1 \mathrm{~g} \text { of } \\
\text { eggs }\end{array}$ & Total no. Eggs \\
\hline Albino(Yola) & $750^{\mathrm{a}}$ & $45.5^{\mathrm{a}}$ & $125^{\mathrm{b}}$ & $998^{\mathrm{c}}$ & $124,750^{\mathrm{c}}$ \\
Normal (Katsina) & $750^{\mathrm{a}}$ & $44.5^{\mathrm{a}}$ & $200^{\mathrm{a}}$ & $1118^{\mathrm{a}}$ & $229,240^{\mathrm{a}}$ \\
Normal(Yola) & $750^{\mathrm{a}}$ & $44.5^{\mathrm{a}}$ & $125^{\mathrm{b}}$ & $1018^{\mathrm{b}}$ & $127,250^{\mathrm{b}}$ \\
\hline
\end{tabular}

Means in each column with the same superscript are not significantly different $(P>0.05)$

The mean milt volume and testes length and weight are shown in Table 2 . The highest milt volume was recorded in the Albino $(8.4 \mathrm{ml})$ while the least was in normal pigmented fish from Katsina. While the weight of the testes was highest in the Albino, this sample has the right ( ) and left lobes values of $17 \mathrm{~g}$ and $30 \mathrm{~g}$, respectively; the normal pigmented from Katsina has the right and left lobes of
$18 \mathrm{~g}$ and $24 \mathrm{~g}$, respectively ; the least values were observed in the normal pigmented from Yola with right and left lobes of $14 \mathrm{~g}$ and $13 \mathrm{~g}$, respectively. However, there were significant variations $(p<0.05)$ in the lengths of the teste $\mathrm{s}$, Albino recorded the highest length of $11.0 \mathrm{~cm}$ while the least was in the Yola $4.5 \mathrm{~cm}$ sample.

Table 2: Mean Testes of Albino and Normal Pigmented Clarias gariepinus Broodstock

\begin{tabular}{|c|c|c|c|c|c|}
\hline $\begin{array}{l}\text { Male } C . \\
\text { gariepinus }\end{array}$ & $\begin{array}{l}\text { Weight right } \\
\text { Testis }(\mathrm{g})\end{array}$ & $\begin{array}{l}\text { Wt. of left } \\
\text { Testis }(g)\end{array}$ & $\begin{array}{l}\text { Length of right } \\
\text { testis }(\mathrm{cm})\end{array}$ & $\begin{array}{l}\text { Length of left } \\
\text { testis }(\mathrm{cm})\end{array}$ & $\begin{array}{l}\text { Sperm } \\
\text { Volume(ml) }\end{array}$ \\
\hline Albino & $17^{b}$ & $30^{a}$ & $5.2^{b}$ & $11.0^{a}$ & $8.4^{a}$ \\
\hline KT. & $18^{a}$ & $24^{b}$ & $5.7^{\mathrm{a}}$ & $4.8^{b}$ & $4.0^{c}$ \\
\hline YL. & $14^{c}$ & $13^{c}$ & $5.0^{c}$ & $4.5^{c}$ & $4.7^{b}$ \\
\hline
\end{tabular}

Means in each column with the same superscript are not significantly different $(P>0.05)$

The results of fertilization and hatchability of genetic crosses between the albino, normal pigmented from Katsina and Yola Clarias gariepinus are shown in Table 3. The highest percentage fertilization was in $\mathrm{KNCg} \times \mathrm{KNCg}$ (98.7), followed by $\mathrm{KNCg} \times \mathrm{ACg}(98.4)$ while others were $\mathrm{ACg} \times \mathrm{ACg}(96.9), \mathrm{YNCg} \times \mathrm{YNCg}$ (96.9), and the least is $\mathrm{ACg} \times \mathrm{YNCg}$ (89.1). There were significant variations $(p<0.05)$ in the fertilization of the respective treatments.
However the highest percentage hatchability was recorded in $\mathrm{KNCg} \times \mathrm{KNCg}(98.5 \%)$, then $\mathrm{KNCg} \times \mathrm{Acg}, \mathrm{YNCg} \times \mathrm{YNCg}, \mathrm{ACg} \times \mathrm{KNCg}, \mathrm{KNCg}$ $\times \mathrm{YNCg}, \mathrm{ACg} \times \mathrm{ACg}, \mathrm{YNCg} \times \mathrm{KNCg}, \mathrm{YNCg} \times$ $\mathrm{ACg}, \mathrm{ACg} \times \mathrm{YNCg}(97.3,95.3,94.6,94.5,94.3$, $94.3,88.9$ and 84.5 respectively. . There were significant variations $(p<0.05)$ in the hatchability of the respective treatments, Yola and Albino, and Albino and Yola cross are with the least hatchability.

Table 3: Percentage Fertilization and Hatchability of Albino and Normal C. Gariepinus

\begin{tabular}{|c|c|c|}
\hline Genetic Crosses & $\%$ Fertility & $\%$ Hatchability \\
\hline & $96.9^{b}$ & $94.3^{c}$ \\
\hline OKT $x$ Ơ KT & $98.7^{\mathrm{a}}$ & $98.5^{a}$ \\
\hline OYY X O'YY & $96.9^{b}$ & $95.3^{b}$ \\
\hline QAA $x 0^{n} \mathrm{KT}$ & $94.7^{c}$ & $94.6^{b c}$ \\
\hline ¡KT $\times O^{\prime \prime} \mathrm{AA}$ & $98.4 \mathrm{ab}$ & $97.3^{a b}$ \\
\hline OKT X OOYY & $95.3^{b c}$ & $94.5^{b c}$ \\
\hline QAA $\times O^{\prime \prime} Y Y$ & $89.1^{\mathrm{e}}$ & $84.5^{b c}$ \\
\hline
\end{tabular}




$\begin{array}{lll}\text { OYY } \times \text { O’AA }^{\mathrm{N}} & 90.7^{\mathrm{d}} & 88.9^{\mathrm{d}} \\ \text { } Y Y \times \text { ơT }^{\mathrm{K} K} & 96.9^{\mathrm{b}} & 94.3^{\mathrm{c}}\end{array}$

Means in each column with the same superscript are not significantly different $(P>0.05)$

Table 4 shows the ratio of albino and normal pigmented Clarias gariepinus. Across the parameters the cross from Katsina (Normal pigmented $148.00 \pm 0.58$ ) had the highest fertility ratio followed by cross between Katsina and albino (147.67 \pm 0.88$)$, and the least was in the cross between the albino and Yola $(133.67 \pm 2.60)$. Same trend was observed in the hatchability rate. The ratio of Albino and Normal pigmented Clarias gariepinus in the crosses was 80:20=4:1

Table 4: Mean Fertilization and Hatchability of Albino and Pigmented C. gariepinus and Their Reciprocal Crosses

\begin{tabular}{lllllll}
\hline Parameter & ALB f $) \times$ & KT $(\mathrm{f}) \times$ & ALB f $) \times$ & $\mathrm{KT} \mathrm{f}) \times$ & $\mathrm{ALB}$ f) $\times$ & $\mathrm{YY} \mathrm{f) \times}$ \\
& $\mathrm{ALB}(\mathrm{m})$ & $\mathrm{KT}(\mathrm{m})$ & $\mathrm{KT}(\mathrm{m})$ & $\mathrm{ALB}(\mathrm{m})$ & $\mathrm{YY}(\mathrm{m})$ & $\mathrm{ALB}(\mathrm{m})$ \\
\hline Fertility & $145.33 \pm 1.7$ & $148.00 \pm 0.5$ & $142.00 \pm 3.0$ & $147.67 \pm 0.8$ & $133.67 \pm 2.6$ & $136.00 \pm 1.1$ \\
& $7^{\mathrm{d}}$ & $8^{\mathrm{d}}$ & $6^{\mathrm{c}}$ & $8^{\mathrm{d}}$ & $0^{\mathrm{a}}$ & $6^{\mathrm{b}}$ \\
Hatchabilit & $141.33 \pm 1.3$ & $147.67 \pm 0.3$ & $141.67 \pm 3.2$ & $146.00 \pm 1.1$ & $126.67 \pm 1.7$ & $133.33 \pm 1.7$ \\
$\mathrm{y}$ & $3^{\mathrm{c}}$ & $3^{\mathrm{d}}$ & $8^{\mathrm{c}}$ & $6^{\mathrm{d}}$ & $6^{\mathrm{a}}$ & $6^{\mathrm{b}}$ \\
\hline
\end{tabular}

Means in each column with the same superscript are not significantly different $(P>0.05)$

\section{Discussion}

Ochokwu et al. (2019) reported that the viability of Egg and sperm is essential for obtaining healthy larvae. The health of the parent stock is relevant and should be considered when using it for hybridization (Ochokwu et al., 2015). However there are other factors that should be considered during hybridization and fish breeding: feeding regime, quality of the feed, age of the broodstock, environmental conditions during the breeding process, motility of the sperm, the sperm volume and viability and physicochemical properties of the water $(\mathrm{pH}$, dissolve oxygen, ammonia content, turbidity, Temperature) (Ochokwu et al., 2015). Hybridization and selective breeding has been the traditional method employed for improving fish (Ochokwu et al., 2016). It has aided in fish productivity whether heritability $\left(\mathrm{h}^{2}\right)$ is large or small, it is used for fish grow out, hybridization is relevant in production of new breeds and strains, for production of uniform progeny in the process of producing mono-sex populations.

In this research, despite having the same weight, there was a significant difference in the fecundity rate. Fecundity is an essential tool in calculating the reproductive potential of a fish. The highest fecundity $(229,240)$ was recorded in the fish obtained from Katsina state (North western part of Nigeria) ; it also had the highest egg weight (200g), while the least fecundity was obtained in the albino fish $(124,750)$. Ndeham et al., (2018) also reported higher fecundity of 240,800 in Katsina samples, which is higher than the value obtained from the present study. However Ochokwu et al. (2016) reported high fecundity in fish obtained from Ibadan than Katsina, the increase in the fecundity of fish is related to weight, length of the fish, the fish habitat/environment.

The weight, length and sperm volume obtained in this research were highest in the albino fish from Yola, while Katsina had the least sperm volume, which agrees with the work of Ochokwu et al., (2016) who reported higher sperm volume in fish from Ibadan than fish from Katsina. However the highest volume of sperm obtained from the albino fish can be attributed to the weight of the fish.

The results of fertilization rate in this research agree with Onyia et al., (2016) who obtained a higher fertilization rate when Normal pigmented was crossed with Albino $C$. 
gariepinus; and also when albino was crossed with albino ; the same trend was recorded by Ochokwu et al. (2016). When genetically improved parent stocks are crossed together, they produce better hybrids ; similarly when genetically improved ones are crossed with wild fish the hybrids give better results when compared with the progeny obtained from the wild breeds. Tilahun et al. (2016) recorded the highest fertility rate in pure breeds of $C$. gariepinus. Subsequently, the parent stock from Katsina had the highest hatchability rate when compared with the other genetic crosses . This agrees with Ochokwu et al., (2016) who recorded the highest hatchability rate in a cross between Ibadan and Ibadan; Onyia et al. (2016) also the reported highest hatchability in Albino $x$ Albino, while Tilahun et al., (2016) recorded the highest hatchability in C. gariepinus when compared with Indian catfish ( $C$. batrachus) and its reciprocal hybrids.

It is most likely to have higher fertility and hatchability from parent stock obtained from within a region than when it is imported from another region due to temperature differences and other environmental factors, subsequently from parent stock which have withstood several adverse environmental conditions.

\section{Conclusion}

The research exposed fecundity and sperm quality of C. gariepinus from Katsina and Adamawa States. The normal pigmented from Katsina had the highest fecundity in this research while albino had the best sperm volume. The research showcased the significance of cross breeding of the same species from different eco-zones. The cross maximized the rate of fertility and hatchability among the genetic crosses. Subsequently the first filial generations (F1) yield better results than the pure breed in the next breeding.

\section{References}

Adah, P.M., Onyia, L.U., and Obande, R.A. (2014). Fish Hybridization in Some Catfishes: A Review. Biotech 13(6):248-251pp

Ndeham, V. R. Ladu, B.M.B. and Onyia, L.U. (2018). Comparison of Fertilization, Hatchability, Growth and Survival of Clarias gariepinus from Adamawa and Katsina States. Adv Life Sci and Tech 53: 1-7
Ochokwu, I. J., Apollos, T.G and Oshoke, J.O. (2015). Effect of Egg and Sperm Quality in Successful Fish Breeding, IOSR J of Agric and Vet Sci 8(8): 48-57pp.

Ochokwu, I.J., Bichi, A.H., and Onyia, L.U. (2016). Intra-specific Hybridization between Two Strains of Clarias gariepinus from SouthWest and North Western Nigeria. Nig J of Fish and Aqua 4(1): $34-41$

Onyia, L.U., B.M.B. Ladu and S.O. Olufeagba (2011) Comparison of growth performance of first and second generations of Clarias anguillaris Hybrids. Adamawa State University J of Sci Research. 1(2):1-6.

Onyia, L.U., Ochokwu, I.J., and Akume, C.P. (2016) Growth and Survival of Normal Coloured and Albino Clarias gariepinus and their Reciprocal Hybrids. Nig J of Fish and Aqua 4(1): $22-27$

Onyia, L.U., Sajo, Z.M., Ochokwu, I.J., and Duwal S.D. (2017). Intra-Specific Hybridization of Clarias gariepinus From Adamawa and Taraba States. Adamawa state J of Agric SCi $5: 42-59$

Onyia, L.U. Philip, B. and Jegede, O. I.(2018). Evaluation of Reproductive Indices and Growth of Normal, Albino, Clarias gariepinus and Their Reciprocals in Hatchery Conditions. J Nat Sci Research 8(16):7-14.

Ochokwu, I. J., Nwabunike, M. O. and Udeh, G. N. (2019). Evaluation of Milt Quality of Clarias Anguillaris (Linnaeus, 1758) Broodstock Fed Varying Inclusion Levels Of Wild Hibiscus Azanza Garckeana Pulp Meal. J of Aqua Sci, 34 (1): 23-31 DOI: https://dx.doi.org/10.4314.jas.v34i1.4

Sazima I. and Pombal, J. Jr (1986) Um albino de Rhamdella minuta, com notas sobre comportamento (Osteichthyes, Pimelodidae). Revista Brasileira de Biologia, 46:377-381.

Tilahun, G., Dube, K., Chtruvedi, C.S., and Kumar, B. (2016) Assessment of Reproductive Performance, Growth and Survival of Hybrids of African Catfish (Clarias gariepinus) and Indian catfish (Clarias batrachus) Compared to Their Parental Lines Crosses. Turk J of Fish and Aqu Sci. 16:123-133 